\title{
Increased Calmodulin in Cultured Skin Fibroblasts from Patients with Cystic Fibrosis
}

\author{
M. E. GNeGY, ${ }^{*}$ R. P. Erickson, $\uparrow+$ and J. Markovac $\dagger$ \\ *Department of Pharmacology and Departments of $\dagger$ Human Genetics and $\ddagger$ Pediatrics, \\ University of Michigan Medical School, Ann Arbor, Michigan 48109
}

Received March 2, 1981

Alterations of both cyclic AMP and calcium metabolism have been found in many cell types from patients with cystic fibrosis (CF). Several groups have reported an increase in intracellular cyclic AMP in CF fibroblasts after stimulation with isoproterenol $(1,2)$. These results have been confirmed by Markovac et al. and are reported in the accompanying paper (3). Markovac et al. (3) also found increased specific binding of the $\beta$-adrenergic ligand, $\left[{ }^{3} \mathrm{H}\right]$ dihydroalprenolol, to the CF-cultured fibroblasts, which could partially account for the increased response to $\beta$ adrenergic agonists found in these cells. Abnormalities in calcium content and metabolism have also been detected in cultured skin fibroblasts from patients with CF. These cells show increased intracellular calcium pools and altered calcium transport across membranes $(4,5)$. The abnormalities in both calcium and cyclic AMP found in CF-cultured skin fibroblasts suggest the possible involvement of calmodulin, an endogenous calciumbinding protein. Calmodulin has been found to affect many calciumdependent activities as well as modulate the cyclic AMP metabolism in many tissues (6). Calmodulin stimulates adenylate cyclase activity as well as phosphodiesterase (PDE) activity in several tissues (6-8) and may play a role in secretion (9). Calmodulin, therefore, could be involved in the increased cyclic AMP induction or abnormal calcium metabolism or secretion in CF fibroblasts. In order to determine whether calmodulin was altered in CF fibroblasts, we measured calmodulin in cultured skin fibroblasts from normal patients and those with $\mathrm{CF}$.

\section{METHODS}

Fibroblasts were obtained either from the Human Genetic Mutant Cell Repository or from patients at the University of Michigan Hospital. The 
cells were cultured, grown, and prepared for assay as described by Markovac et al. (3). The calmodulin content was determined in homogenate fractions from normal and CF fibroblasts. Fibroblast cells were washed in $\mathrm{Ca}^{2+}, \mathrm{Mg}^{2+}$-free buffer, scraped with a rubber policeman, and centrifuged at $800 \mathrm{~g}$ for $10 \mathrm{~min}$. The cells were resuspended in $50 \mathrm{~mm}$ piperazine- $N, N^{\prime}$-bis(2-ethanesulfonic acid) (Pipes) buffer, $\mathrm{pH} 7.0$, and sonicated for $5 \mathrm{~min}$ to disrupt the cells and membranes. The homogenate preparations were heated at $95^{\circ} \mathrm{C}$ for $2 \mathrm{~min}$. This treatment destroys endogenous PDE activity but leaves calmodulin active. The calmodulin content in sample aliquots (5-20 $\mu \mathrm{g}$ of protein) was determined by its ability to activate a calmodulin-deficient brain PDE (10) using the PDE assay described previously (11). The calmodulin content was measured in nanograms using a standard curve obtained with highly purified calmodulin prepared from bovine brain (12). Protein was determined by the method of Lowry et al. (13) using bovine serum albumin as a standard.

PDE activity in the normal and CF fibroblasts was measured using concentrations of cyclic AMP of 1 and $100 \mu \mathrm{M}$ to distinguish the high and low $K_{m}$ forms of PDE in hydrolyzing cyclic AMP. The calcium sensitivity of the high $K_{m}$ form was shown by the addition of $100 \mu \mathrm{M}$ EGTA.

\section{RESULTS}

The calmodulin content in homogenate fractions of cultured skin fibroblasts from $8 \mathrm{CF}$ and 12 normal lines is shown in Table 1 . The cells were grown and treated under the same conditions in which the increased cyclic AMP induction after metaproterenol treatment was found (3). The cells were always at the same stage of confluency and were presented blind. The data in Table 1 demonstrate that there was an overall increase of $60 \%$ in the calmodulin content of CF fibroblasts over normal controls. There is some overlap with the values for normal cells. This could partly reflect day to day variation in assay techniques because in any one day there was always a greater calmodulin content in the CF cells. The average $\mathrm{CF} / \mathrm{N}$ ratio for each experiment was $1.6 \pm 0.1 \mathrm{SEM}$. This increase was significant by the Wilcoxon rank sum test at $P<0.002$. Passage number did not affect the calmodulin content; cells were used from 5 to 30 passages.

The increased induction of cyclic AMP in CF fibroblasts could be partially due to decreased PDE activity. Preliminary data suggest, however, that PDE activity is not altered in the CF cells. PDE activity measured using $1 \mu \mathrm{M}$ cyclic AMP was $194 \pm 29 \mathrm{pmole} / \mathrm{min} / \mathrm{mg}$ protein in seven normal lines and $185 \pm 27 \mathrm{pmole} / \mathrm{min} / \mathrm{mg}$ protein in five $\mathrm{CF}$ lines. The PDE measuring using $100 \mu \mathrm{M}$ cyclic AMP was sensitive to inhibition by EGTA, a calcium chelating agent. This suggests that calcium 
TABLE 1

Calmodulin Content in Fibroblasts from Cystic Fibrosis and Normal Cell Lines

\begin{tabular}{llc} 
Cell line & $N^{a}$ & $\begin{array}{c}\text { Calmodulin concentration } \\
\text { (ng/ } \mu \text { g protein } \pm \text { SEM) }\end{array}$ \\
\hline CF Line & 7 & $1.9 \pm 0.2$ \\
GM 1957 & 5 & $2.0 \pm 0.3$ \\
GM 1958 & 4 & $3.1 \pm 0.4$ \\
GM 1959 & 7 & $2.5 \pm 0.3$ \\
GM 0768 & 3 & $2.3 \pm 0.1$ \\
GM 770 & 2 & $1.95 \pm 0.07$ \\
GM 2801 & 2 & $3.6 \pm 0.3$ \\
GM 851 & 2 & $1.7 \pm 0.1$ \\
GM 192 & & $-2.4 \pm 0.2 *$ \\
& & \\
Normal Line & 3 & $1.6 \pm 0.1$ \\
872 & 3 & $1.5 \pm 0.2$ \\
982 & 2 & $1.45 \pm 0.2$ \\
UP-AFC & 2 & $2.2 \pm 0.1$ \\
TB-N & 1 & 1.8 \\
MODY-1 & 2 & 1.0 \\
NF-B & 2 & $1.45 \pm 0.1$ \\
1998 & 1 & 0.95 \\
MODY-A & 1 & 1.0 \\
MODY-B & 4 & $1.7 \pm 0.2$ \\
RC-N & 2 & $1.4 \pm 0.1$ \\
NF-D & 1 & $2.2 \pm$ \\
NF-F & & $1.5 \pm 0.1$ \\
& & $X$ \\
\hline
\end{tabular}

${ }^{a}$ Number of determinations.

${ }^{*} P<0.002$ with respect to the value for normal cells.

and calmodulin are required for this activity. The PDE activity measured at $100 \mu \mathrm{M}$ cyclic AMP was $2.08 \pm 0.2 \mathrm{nmole} / \mathrm{min} / \mathrm{mg}$ protein in seven normal lines and $1.9 \pm 0.3 \mathrm{nmole} / \mathrm{min} / \mathrm{mg}$ protein in five $C F$ lines.

\section{DISCUSSION}

We have shown that cultured skin fibroblasts from patients with $\mathrm{CF}$ have greater calmodulin-like activity compared to those from normal controls. The increase in calmodulin parallels the findings of increased induction of cyclic AMP by $\beta$-adrenergic agonists (1-3), greater density of $\beta$-adrenergic receptors (3), and increased calcium concentration (4) found in CF fibroblasts. Thus, it seems that calmodulin is part of the generalized "up" regulation of the $\beta$-adrenergic and calcium system in the CF fibroblasts. It is highly possible that calmodulin is contributing 
to the increased induction of cyclic AMP in these cells as well as other calcium-related activities. At the present time, the function of calmodulin in these fibroblasts is not known. Calmodulin has been shown to stimulate adenylate cyclase activity in nervous tissue $(6,14)$ in pancreatic islet cells (7), and chick embryo fibroblasts (8). PDE and $\mathrm{Ca}^{2+}, \mathrm{Mg}^{2+}$-ATPase activities in many tissues are also stimulated by calmodulin (6). Furthermore, a role for calmodulin has been suggested in the secretion of insulin (9).

The increased calmodulin-like activity in the CF cells does not seem to be affecting the PDE activity even though the high $K_{m}$ PDE is most likely calmodulin dependent. Epstein et al. (15) found similar results for low $K_{m}$ cyclic AMP PDE activity in CF fibroblasts. Although calmodulin stimulates $\mathrm{Ca}^{2+}, \mathrm{Mg}^{2+}$-ATPase activity in many cell types (6), this activity is decreased in CF fibroblasts (16). This is not too surprising since increased calcium levels can begin to inhibit this enzyme. It is further possible that the increase in calmodulin-like activity in CF cells is largely located in the membranes, and affects adenylate cyclase activity. For example, the membrane content of calmodulin is increased in the striatum of rats showing behavioral supersensitivity to dopamine and having increased dopamine-sensitive adenylate cyclase activity (14).

The assay used to detect calmodulin measures calmodulin activity in stimulating PDE activity. Therefore the increase in calmodulin could be due to either an increase in calmodulin activity or in the amount of calmodulin. We plan to measure calmodulin using a radioimmunoassay that will definitely determine whether calmodulin activity or content is altered in CF fibroblasts. There was some overlap in the values for the calmodulin content in the CF fibroblasts and normal cells. This suggests that the alterations in this variable are not the primary gene defect in CF. It could, however, be related to the primary gene defect and be an immediate expression of the defect. Further investigation in the area may lead us to the primary lesion in $\mathrm{CF}$.

\section{SUMMARY}

We have found that the content of an endogenous calcium-binding protein, calmodulin, is greater in cystic fibrosis fibroblasts than in normal cells. Homogenate preparations from CF fibroblasts contained $2.4 \pm 0.2$ $\mathrm{ng}$ calmodulin $/ \mu \mathrm{g}$ protein while normal fibroblasts contained $1.5 \pm 0.1$ ng calmodulin/ $\mu \mathrm{g}$ protein. Cyclic AMP phosphodiesterase activity, however, was the same in cystic fibrosis and normal fibroblasts. The increased calmodulin in cystic fibrosis cells could be involved in the changes in calcium metabolism and cyclic AMP production found in these cells. 


\section{ACKNOWLEDGMENTS}

This work was supported by NSF Grant BNS 78-06964. We thank Glenn Treisman for his excellent technical assistance.

\section{REFERENCES}

1. Buchwald, M., Proc. Nat. Acad. Sci. USA 73, 2899 (1976).

2. Roscher, A. A., Schmid, A. J., Hadorn. B., and Weisman, U. N., Pediatr. Res. 14, 261 (1980).

3. Markuvac, J., Erickson, R. P., and Hieber, V., Biochem. Med. 26, 299 (1981).

4. Shapiro, B. L., Fiegal, R. J., Laible, N. J., Biros, M. H., and Warwick, W. J., Clin. Chim. Acta 82, 125 (1978).

5. Feigal, R. J., and Shapiro, B. L., Pediatr. Res. 18, 764 (1979).

6. Cheung, W. Y., Science 207, 19 (1980).

7. Valverde, I., Vandermeers, A., Anjaneyulu, R., and Malaisse. W. J., Science 206, 225 (1979).

8. LaPorte, D. C., Gidwitz, S., Weber, M. J., and Storm, D. R., Biochem. Biophys. Res. Commun. 86, 1169 (1979).

9. Schubart, U. K., Erlichman, J., and Fleischer, N., J. Biol. Chem. 255, 4120 (1980).

10. Klee, C. B., and Krinks, M. H., Biochemistry 17, 120 (1978).

11. Gnegy, M. E., Nathanson, J. A., and Uzunov, P., Biochim. Biophys. Acta 497, 75 (1977).

12. Klee, C. B., Biochemistry 16, 1017 (1979).

13. Lowry, O. H., Rosebrough, N. J., Farr, A. L., and Randall, R. J., J. Biol. Chem. 193, 265 (1951).

14. Gnegy, M. E.. Lau, Y. S., and Treisman, G., Ann. N.Y. Acad. Sci. 356, 304 (1981).

15. Epstein, J., Breslow, J. L., Fitzsimmons, M. J., and Vayo, M. M., Somat. Cell Genet. 4, 451 (1978).

16. Katz, S., Res. Commun. Chem. Pathol. Pharmacol. 19, 491 (1978). 